\title{
Application of Group Investigation Model to Increase Learning Outcomes of Elementary School Students
}

Rizki Yuanita*, I Nyoman Sudana Degeng, Sudarmiatin

Graduate Program of Elementary Education, Universitas Negeri Malang, Malang, Indonesia.

\begin{tabular}{l|l}
\hline \multicolumn{1}{c|}{ A R T I C LE I N F O } & \multicolumn{1}{c}{ A B S T R A C T } \\
\hline $\begin{array}{l}\text { Received: 09-03-20I7 } \\
\text { Revised: 08-05-2017 } \\
\text { Accepted: 07-06-20I7 }\end{array}$ & $\begin{array}{l}\text { This research aims to improve student learning outcomes on care for living things } \\
\text { through the application of group investigation model can theme. The research } \\
\text { method was classroom action consisting two cycles with subjects were the 4th grade } \\
\text { students of Pemurus Baru I Public Elementary School academic year 2017/2018, } \\
\text { total sample 30 students, and data collected through evaluation test. The results } \\
\text { showed that by using study group investigation, the student learning outcomes } \\
\text { increase. }\end{array}$ \\
$\begin{array}{l}\text { Group investigation, } \\
\text { learning outcomes }\end{array}$ & $\begin{array}{l}\text { C 2018 The Authors. Journal of K6, Education, and Management (j-K6EM). ISSN: 2580-2135. } \\
\text { Published by Graduated Program of Educational Management, Universitas Lambung } \\
\text { Mangkurat, Banjarmasin, Indonesia. This is an open access article under the open journal } \\
\text { systems 3. }\end{array}$ \\
\hline
\end{tabular}

*Author correspondence: Rizki Yuanita; E-mail: rizki.yuanita@gmail.com 


\section{Introduction}

In a teaching and learning process, there are expected results. According to Sugiartini et al. (20I4), a result obtained from teaching and learning activities are referred to as learning outcomes. Sanjaya (2010) said that learning outcomes can be said to be successful if learners make achievement in accordance with the specific objectives that have been planned. According to Bloom, learning outcomes may include cognitive, affective and psychomotor aspects.

Learning outcome can be produced from assignments such as project or evaluation. In addition, Rahmawati (2012) said that learning outcome can be the abilities mastered by students after receiving a learning experience that can be seen from the change of behavior. But it is still unfortunate that the results obtained are still not satisfactory, meaning it is still below the expected standards.

Based on temporary observation, learning outcome and achievement of 4th grade students at Pemurus Baru I Public Elementary School Banjarmasin, academic year 2017/2018 on "care for living things" theme of Natural Science still has not achieved satisfactory results. This is evidenced from the fact that many students still have low learning outcomes. From the classical mastery score of 4 th grade students Semester I of $2017 / 2018$, only $43.3 \%$ students were able to exceed the predefined standard score. From 30 students, I7 students were included under minimum mastery criteria score of 65 .

This is because there are still many students who keep silent and lack of motivation in following the lesson or passive and reluctant to ask the teacher, so that the students are still lack of knowledge. One of the causal factors is the strategy or learning model that is not enough to be applied. If the issue is not addressed, then some problems might occur, for example it will be very difficult for students to achieve learning outcomes in accordance with the standards set by the school.

There are several things that may affect learning outcomes such as teacher, infrastructure, learning environment, method, media and learning model. Maximum learning outcome according to
Susiloningrum et al. (2016) can be obtained if it is supported by several factors such as the use of right method, model and strategy. One model that can be used to increase the learner learning outcome is Group Investigation (GI) model.

Group Investigation (GI) can increase the learner motivation that is expected to improve the learner learning outcome. The same thing is also conveyed by Indrayani et al. (2017) that learning activities that are in accordance with the learner characteristics, study group formation, use of media and appropriate learning model are very effective in increasing the student learning motivation.

According to Sulasti (2013), GI is a learning model that can develop student skill in thinking, analyzing and solving the problem. If learners are directly involved in the process of analyzing and solving problems, it will make them to be more sensitive in seeing the problem, so that the learning outcomes increase.

The other expected learning outcomes in addition to analyze and solve their own problems is the increase in cognitive, affective, and psychomotor aspect. Primarinda et al. (20I2) said that GI is a cooperative learning model that can build all aspects of student skills in terms of cognitive, affective, and psychomotor. And this learning model not only focuses on the development of individual, but also the social aspects of students to work in groups.

\section{Methodology}

A good methodology should bring the researcher to achieve of the objective (Dalle, 2010; Dalle et al., 2017). This study used qualitative naturalistic approach where the research was performed on natural setting. It emphasized the meaning, definition context, and things related to classroom learning while the research type was classroom action research (CAR). Qualitative research did not generalize but emphasizes the depth of information so that it reached the level of meaning (Sugiyono, 20I I).

Classroom action research is a process of reflective observation of learning activities performed by teachers to improve learning quality 
and increase student learning outcome (Jalil, 20I4).

According to Wardhani (2010), CAR is a research conducted by teachers in their own class through self-reflection aiming to improve teacher performance, so that student learning outcomes increase. Some experts propose action research mode with different charts, but in a broad outline there are four stages that must be passed, namely: a) Planning, b) Implementation, c) Observation, and d) Reflection.

Class action research is an action research conducted aiming to improve the quality of classroom learning practice (Arikunto, 2012). This research was very useful for teachers to improve the process quality and increase learning outcomes in the classroom since it raised the actual problems faced by teachers in the field.

This research was conducted in academic year 2017/20I8 semester I at Pemurus Baru I Publci Elementary School with 30 students consisting of I3 boys and 17 girls. The factor studied was student learning outcome on "care for living things" theme.

This research presented quantitative data in the form of learning outcome measurement performed at each end of the cycle using GI model to obtain score test. The success indicator used in this research was individual learning mastery of $\geq 65$ based on KKM in the theme mentioned. In classical mastery, the success indicator reached at least $80 \%$ of the total students who got $\geq 65$.

\section{Results and Discussion}

Student learning outcome data was obtained from the evaluation test conducted at the end of each meeting in order to measure student ability in mastering the material that has been given and added by the final cycle evaluation covering all the learning materials at the meetings.

Based on the results of evaluation test conducted on cycle I and cycle II, classical mastery of student learning outcome continues to increase. In cycle I - meeting $\mathrm{I}$, the classical mastery of $63.34 \%$ increased to $73.34 \%$ at meeting 2 . While on cycle II - meeting I, the classical mastery of $83.34 \%$ increased to $96.66 \%$ at meeting 2and managed to achieve the classical mastery set by the researchers.

After the implementation of group investigation model, there is an increase in learning outcomes on "care for living things" theme of Natural Science. As we see in table one, in cycle I meeting I, the classical mastery of $63.34 \%$ or 19 students who passed had increased to $73.34 \%$ where 22 students passed. While in cycle II meeting I, the classical mastery of $83.34 \%$ or 25 students who passed had increased to $96.66 \%$ where 29 students have mastered the subject.

Student learning outcomes on "care for living things" theme of natural science using cooperative group investigation model in cycle II has reached the success indicator expected by the researchers. In this second cycle, the students have understood the lesson delivered by teachers and they have become more enthusiastic about learning. As a result, the student learning outcomes increase from not mastered into mastered. This is because GI model requires students to conduct their own research into the problems they face starting from gathering information, analyzing, until finding the result. Similarly, Rahmawati (20I2) also stated that GI model can help the students to be directly involved in solving problems, so that they become more sensitive to the problems in order to increase student learning outcomes.

In addition, according to the perspective of Government Regulation Number I9 of 2005, specifically Chapter IV Article I9 in Suriansyah, et al (20I4), it expressly states that learning process in an education is organized: I) Interactively, 2) Inspirationally, 3) Fun, 4) Challenging, 5) Motivate learners to participate actively. To achieve these five aspects, it is necessary to use the right learning model. According to Listiana (20I3), GI is a learning model that can create an interactive, more challenging and fun atmosphere because it requires the students to conduct research where cooperation and interaction to find information are necessary. With a fun learning atmosphere, both learning motivation and learning outcome of student will increase.

The similar thing also has been expressed by Indrastuti et al. (2017) who states that if the students involve and interact directly with the source of information, then they will understand 
the material taught better, so a good learning outcome is obtained. When students engage directly with the object of problem, it will create meaningfulness in the learning process. Therefore, to create a meaningful learning situation, it is necessary to have an appropriate learning model namely GI.

Based on the results of research that has been conducted, the application of GI learning model can improve student learning outcomes. Before the classroom action research aiming to determine the initial condition of students, the student learning outcomes on "care for living things" theme of natural science is still low. Students tend not to be motivated to follow the learning process. Consequently, the student learning outcomes also decrease. In addition, after action research with GI model in cycle I and cycle II was applied on "care for living things" theme, the learning outcomes increase

\section{Conclussion and Recomendations}

Based on the research results, it can be concluded that the student learning outcomes on "care for living things" theme of natural science can increase by using cooperative learning model of GI. It is shown on classical mastery cycle I meeting I (63.34\%), cycle I - meeting 2 $(73.34 \%)$, and cycle II - meeting I (83.34\%) that increase to $96.66 \%$ in cycle II - meeting 2 . This proves that GI learning model used by the researchers is appropriate and in accordance with the material taught. It is supported by the results of learning conducted at the end of each meeting both in cycle II and cycle II that continues to increase.

Teachers should improve the learning quality in the classroom. Rather than using lecture method, it is better for the teachers to use appropriate learning methods and models to optimize and improve the teaching quality of teachers as well as to increase student learning outcomes. For example, teachers can use group investigation learning model on learning with "care for living things" theme of natural science.

\section{Acknowledgment}

No acknowledgment

\section{References}

Arikunto, S. (2010). Penelitian tindakan kelas. Jakarta: Bumi Aksara.

Dalle, J. (20I0). Metodologi umum penyelidikan reka bentuk bertokok penilaian dalaman dan luaran: Kajian kes sistem pendaftaran siswa Indonesia. Thesis PhD Universiti Utara Malaysia.

Dalle, J., Hadi, S., Baharuddin., \& Hayati, N. (2017). The Development of Interactive Multimedia Learning Pyramid and Prism for Junior High School Using Macromedia Authorware. The Turkish Online Journal of Educational Technology, November. 7I4-72I.

Indrastuti, W., Utaya, S., \& Irawan, E.B. (2017). Peningkatan Aktivitas Hasil Belajar Siswa Melalui Pembelajaran Kooperatif Tipe Make A Match. Jurnal Pendidikan: Teori, Penelitian, dan Pengembangan, Jurnal Pendidikan: Teori, Penelitian, dan Pengembangan. 8(2), I037-1042.

Indrayani, S., Degeng, I.N.S., Sumarmi. (2016). Pembelajaran Kooperatif Teams Games Tournaments Sebagai Model yang Efektif untuk Meningkatkan Motivasi dan Hasil Belajar Siswa, Prosiding Seminar Nasional Mahasiswa Kerjasama Direktorat Jenderal Guru Dan Tenaga Kependidikan Kemendikbud 2016. 1. $1-9$.

Jalil, J. (20I4). Panduan mudah penelitian tindakan kelas (ptk). Jakarta: Prestasi Pustakarya.

Primarinda, I., Maridi \& Marjono. (20I2). Pengaruh Model Pembelajaran Kooperatif Learning Tipe Group Investigation (GI) Terhadap Keterampilan Proses Sains Dan Hasil Belajar Biologi Siswa Kelas X SMA Negeri 4 Surakarta Tahun Pelajaran 20II/20I2, Pendidikan Biologi. 2(4), 60- 7I.

Rahmawati, D.E. (20I2). Penerapan model pembelajaran kooperatif tipe group investigation (gi) untuk meningkatkan keaktifan belajar dan hasil belajar mata pelajaran sosiologi pada siswa kelas x 3 sma negeri colomadu tahun pelajaran 2011/2012, Jurnal Sosialitas. 2(1). -6.

Sanjaya, W. (2010). Perencanaan dan desain sistem pembelajaran. Jakarta: Rineka Cipta.

Sugiartini, N.N.A, Ardana, I.K., Kristiantari, M.G.R. (20I4). Model pembelajaran modified free inquiry bernuansa outdoor study berpengaruh terhadap hasil belajar ipa siswa kelas v sd gugus 2 kuta utara tahun ajaran 2013/2014. Jurnal Mimbar PGSD Universitas Pendidikan Ganesa, I(2). I-II.

Sugiyono. (201I). Metode Penelitian Kuantitatif dan Kualitatif dan R\&D. Bandung: Alfabeta.

Sulasti, N.W. (20I3). Penerapan model pembelajaran kooperatif tipe group investigation (gi) untuk meningkatkan aktivitas dan hasil belajar siswa dalam pelajaran pkn di kelas xi ipa I sma negeri I sawan tahun ajaran 2012/2013, Jurnal Pendidikan PKn. 4(I), I-I2. 
Suriansyah, A., Aslamiah., Sulaiman., \& Noorhapizah. 20I4. Strategi pembelajaran. Jakarta: Raja Grafindo Persada.

Susiloningrum, Thowaf, S. M., \& Sudarmiatin. (2016). Pembelajaran IPS Melalui Model Problem Based Leaning Sebagai Upaya meningkatkan Hasil Belajar, Prosiding Seminar Nasional Mahasiswa Kerjasama Direktorat Jenderal Guru Dan Tenaga Kependidikan Kemendikbud 2016. I, I-6.

Wardani, I.G.A.K., \& Wihardit, K. (2010). Penelitian tindakan kelas. Jakarta: Universitas Terbuka. 
ISSN 2580-2135 